\title{
A Distinct Pattern of Trophic Factor Expression in Myelin-Deficient Nerves of Trembler Mice: Implications for Trophic Support by Schwann Cells
}

\author{
Hana C. Hyman Friedman, Tony N. Jelsma, Garth M. Bray, and Albert J. Aguayo \\ Centre for Research in Neuroscience, Montréal General Hospital Research Institute and McGill University, Montréal, \\ Québec, Canada H3G 1 A4
}

\begin{abstract}
Distal to a peripheral nerve transection, myelin degradation and Schwann cell (SC) proliferation are accompanied by a marked upregulation of brain-derived neurotrophic factor (BDNF) and a decrease of ciliary neurotrophic factor (CNTF) in non-neuronal cells. To investigate the role of SC differentiation in trophic factor regulation, we studied BDNF and CNTF expression in sciatic nerves from Trembler-J (Tr-J) mice. In these animals, a mutation in the pmp-22 gene causes a failure of myelination and continuous SC proliferation, but axonal continuity is preserved. In spite of the severe abnormalities in Tr-J nerves, BDNF levels remained as low as in the intact controls. Thus, the primary SC disorder in $T r-J$ produces a different pattern of BDNF expression from that caused by axonal breakdown due to nerve transection. Furthermore, the upregulation of BDNF mRNA triggered by transection was 70 -fold in control nerves,
\end{abstract}

but only 30 -fold in Tr-J sciatic nerves. Because these results raised the possibility that axonal loss may influence neurotrophin expression only in SCs that have differentiated toward a myelinating phenotype, we measured BDNF mRNA after axotomy in the cervical sympathetic trunk (CST), a predominantly unmyelinated autonomic nerve. In contrast to the sciatic nerves, the BDNF mRNA level barely increased in the injured CST, supporting the idea that not all SCs are equal sources of trophic molecules. In Tr-J sciatic nerves, CNTF mRNA levels were fourfold lower than normal, implying that the downregulation of this cytokine is a sensitive indicator of a spectrum of SC perturbations that affect myelinating cells.

Key words: axon-Schwann cell interactions; Trembler; demyelination; CNTF; BDNF; injury responses; Schwann cell differentiation
In the peripheral nervous system (PNS), interactions between neurons and non-neuronal cells play key roles in Schwann cell (SC) differentiation, myelin formation, and axon development (for review, see Reynolds and Woolf, 1993; Mirsky and Jessen, 1996). For example, axons influence SC division (Salzer et al., 1980), probably via neuregulins such as glial growth factor (Marchionni et al., 1993). Conversely, myelinating SCs modulate axon caliber through a process that may involve neurofilament phosphorylation (de Waegh et al., 1992).

SCs are also a source of cytokines and neurotrophins that can affect the survival, differentiation, and growth of neurons (for review, see Bunge, 1993). The expression of these molecules changes during development, suggesting that axon-SC interactions influence their production in peripheral nerves. For instance, ciliary neurotrophic factor (CNTF) expression increases as myelination progresses (Sendtner et al., 1994). In contrast, only low levels of brain-derived neurotrophic factor (BDNF) are present in SCs of either developing or mature nerves (Acheson et al., 1991; Schecterson and Bothwell, 1992). The loss of axons, as occurs in the distal stump of a transected sciatic nerve, affects the

\footnotetext{
Received April 4, 1996; revised June 6, 1996; accepted June 11, 1996.

This work was supported by the Multiple Sclerosis Society of Canada, the Canadian Neuroscience Network, and the Medical Research Council of Canada. We thank Jane Trecarten, Margaret David, Sören Singel, Yi-Chun Wang, and Wendy Wilcox for technical assistance. We also gratefully acknowledge receipt of the GAPDH PCR primers and quantitation standard from Dr. D. Radzioch (Centre for the Study of Host Resistance, Montreal General Hospital Research Institute) and the BDNF and CNTF cDNAs from Dr. R. J. Dunn (Centre for Research in Neuroscience, Montreal General Hospital Research Institute).

Correspondence should be addressed to Albert J. Aguayo, Centre for Research in Neuroscience, 1650 Cedar Avenue, Montréal, Québec, Canada H3G 1A4. Copyright (C) 1996 Society for Neuroscience $0270-6474 / 96 / 165344-07 \$ 05.00 / 0$
}

proliferation and differentiation of SCs and dramatically changes their expression of both BDNF and CNTF. The levels of BDNF mRNA, which are barely detectable in the intact nerve, increase 40 -fold in the SCs of these injured nerves. Furthermore, BDNF expression only returns to normal when the regeneration of axons restores neuron-SC contacts (Meyer et al., 1992; Funakoshi et al., 1993). Conversely, the high levels of CNTF in intact nerves (Williams et al., 1984) rapidly fall by nearly $100 \%$ after sciatic nerve transection and remain low until axonal regeneration is completed (Friedman et al., 1992; Sendtner et al., 1992b).

Much of the information concerning the effects of a disruption of axon-SC interactions has arisen from studies that involve the experimental interruption of myelinated axons. Here we have investigated the relationships between SC differentiation toward myelination and trophic factor expression in two situations. First, we examined BDNF and CNTF mRNA expression in the Trembler-J (Tr-J) mutant mouse, which has a point-mutation in the gene for the peripheral myelin protein pmp-22 (Suter et al., 1992). In $T r-J$ peripheral nerves, SC myelin formation is deficient, the few lamellae that form break down (Ayers and Anderson, 1973), and SC division continues throughout life (Perkins et al., 1981). Second, because many fibers in normal autonomic and sensory nerves remain unmyelinated in the mature animal, we measured BDNF mRNAs in one such nerve, the cervical sympathetic trunk (CST) before and after axonal interruption to determine whether growth factor expression is indeed influenced by the SC's acquisition of the myelinating phenotype. This investigation of BDNF expression in the CST was further prompted by the finding that neither CNTF mRNA nor CNTF protein has been detected in unmyelinated fibers (Friedman et al., 1992). 


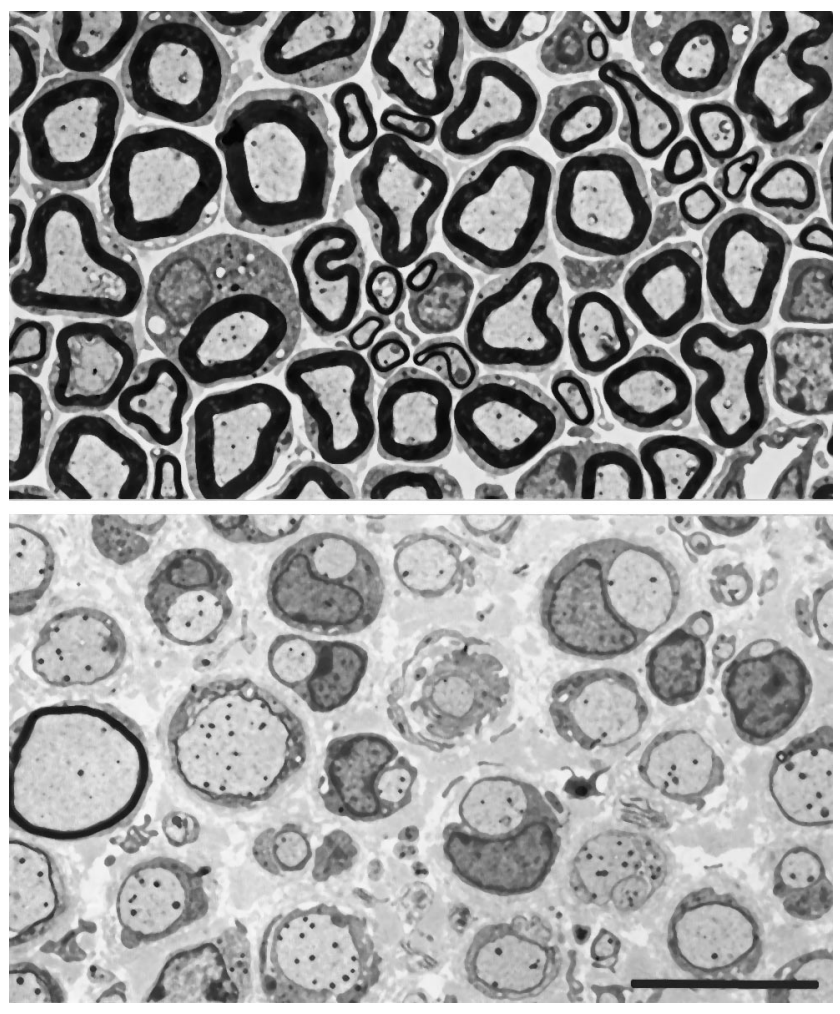

Figure 1. Electron micrographs of transverse sections from normal (top) and $\operatorname{Tr}-J$ (bottom) ventral roots. In the Tr-J nerves, most axons are ensheathed by SC cytoplasm without myelin. A few axons are thinly myelinated. There are more SC nuclei in the $\operatorname{Tr}-J$ nerve than in the control nerve. Scale bar, $10 \mu \mathrm{m}$.

\section{MATERIALS AND METHODS}

Animals and surgical procedures. Tr-J heterozygous mice were purchased from Jackson Laboratories (Bar Harbor, ME). C57Bl/6J mice, either littermates or closely age-matched, were used as controls. The Tr-J mutation was confirmed by clinical and morphological criteria (Ayers and Anderson, 1973) (Fig. 1). Adult $T r-J$ and C57Bl/6J control mice (3-6 months old, $\sim 20-30 \mathrm{gm}$ in weight) were anesthetized with ketamine $(100-200 \mathrm{mg} / \mathrm{kg})$ and xylazine $(7-10 \mathrm{mg} / \mathrm{kg})$. The sciatic nerve was exposed and cut $\sim 1 \mathrm{~cm}$ proximal to the origin of the common peroneal nerve. To avoid axonal regrowth, each end was ligated and sutured to the adjacent muscle with 6-0 silk. After appropriate survival times, the animals were anesthetized, and distal segments of the cut nerves were removed and immediately homogenized in a guanidinium isothiocyanate solution for RNA extraction. The contralateral nerves were used as intact controls for the experiments involving injury.

Adult Sprague Dawley (Charles River, St. Constant, Québec, Canada) rats were used to study the unmyelinated nerve fibers of the CST. Because of the small size of this nerve, rats were used instead of mice. One CST was crushed with jeweller's forceps or cut with scissors $\sim 8 \mathrm{~mm}$ below the superior cervical ganglion. Interruption of the CST was confirmed by ptosis of the ipsilateral eyelid and by histological analysis of a portion of the nerve. The contralateral CSTs were used as control unmyelinated nerves.

$R N A$ preparation and $c D N A$ synthesis. Three to five sciatic nerves or four to six CSTs were homogenized in guanidinium isothiocyanate solution using a hand-held ground-glass homogenizer. RNA was extracted according to the guanidinium isothiocyanate/phenol method (Chomczynski and Sacchi, 1987). After one phenol/chloroform extraction and isopropanol precipitation, RNA was resuspended in water with $1 \mathrm{U} / \mu \mathrm{l}$ RNase inhibitor (RNAguard, Pharmacia Biotech) and treated with 0.01 $\mathrm{U} / \mu$ l DNase I (Amplification Grade, BRL, Bethesda, MD) for $40 \mathrm{~min}$ at $21^{\circ} \mathrm{C}$ to remove contaminating genomic DNA. This was followed by two phenol/chloroform extractions and ethanol precipitation. RNA was reverse-transcribed using $10 \mathrm{U} / \mu \mathrm{l}$ M-MLV Reverse Transcriptase RNase H Minus (Promega, Madison, WI) with 100 pmol of random hexamers
(Pharmacia Biotech) in the presence of $1 \mathrm{~mm}$ deoxynucleoside triphosphates (dNTPs; Pharmacia Biotech) and $1 \mathrm{U} / \mu \mathrm{l}$ RNase inhibitor. The reaction mixtures were incubated at $21^{\circ} \mathrm{C}$ for $10 \mathrm{~min}, 42^{\circ} \mathrm{C}$ for $50 \mathrm{~min}$, and $92^{\circ} \mathrm{C}$ for $3 \mathrm{~min}$ (Kawasaki and Wang, 1989). As a control, an equal aliquot of RNA was processed without the addition of reverse transcriptase.

$P C R$. PCR was performed using $1 \mu \mathrm{l}$ cDNA from the reverse transcription (RT) reaction per $20 \mu \mathrm{l}$ total reaction mixture in $1 \times$ PCR buffer (BRL) with $1.5 \mathrm{~mm} \mathrm{MgCl}_{2}, 0.2 \mathrm{~mm}$ dNTPs, $0.5 \mu \mathrm{M}$ of each sequencespecific primer, and 1.5 U Taq DNA Polymerase (BRL). The mixture was heated to $94^{\circ} \mathrm{C}$ for $3 \mathrm{~min}$ and then cycled 30 times as follows: $1 \mathrm{~min}$ at $94^{\circ}$, $0.5 \mathrm{~min}$ at $62^{\circ}, 1 \mathrm{~min}$ at $72^{\circ}$ (Coen, 1991). PCR products were run on $1.2 \%$ agarose gels with $0.5 \mu \mathrm{g} / \mathrm{ml}$ ethidium bromide and photographed with Polaroid Type 55 positive-negative film. Densities were measured from the negatives using a SciScan 5000 densitometer. The sequence-specific primers used for amplification were 5'-GAGCTGAGCGTGTGTGACAG-3' and 5'-CTCGACTCGCACACACTGTC-3' for BDNF and 5'CCCTTCATTGACCTCAACTACATGG-3' and 5'-GGTAGTGACGGTGGGTCTTCTGA-3' for glyceraldehyde-3-phosphate dehydrogenase (GAPDH), used as an internal control. The sequences of the BDNF primers are common to both mouse and rat BDNF; only 7 base pairs (bp) are different in the entire coding region of the two genes so that amplification should be equally efficient for either.

Competitive PCR. The competitive PCR method of Gilliland et al. (1990) was used for precise cDNA quantitation. This technique requires the addition of a competitor DNA that differs from the cDNA of interest by a small, yet detectable, internal change (deletion or mutation). The same primers coamplify the cDNA and a known amount of competitor. The two species are subjected to the same amplification so that the ratio of their products should remain constant. The relative amount of each product can be determined by running them on appropriate separating gels followed by densitometric scanning.

A $750 \mathrm{bp}$ rat BDNF cDNA cloned into pGEM 7Z (pBDNF 1.0) was provided by Dr. R. J. Dunn (Centre for Research in Neuroscience, Montreal General Hospital Research Institute). To construct the BDNF competitor template, pBDNF 1.0 was digested with Pst I to remove an internal 121 bp PstI fragment. A GAPDH cDNA clone and deletion standard (92 bp internal deletion) were provided by Dr. D. Radzioch (Centre for the Study of Host Resistance, Montreal General Hospital Research Institute).

Five serial dilutions of the DNA competitor were amplified with equal aliquots of the products of RT (cDNA pool). Because the cDNA and deletion construct were amplified with equal efficiency, the starting concentration of the specific cDNA could be determined from the dilution of the standard at which the intensity of their PCR products are equal. In separate PCR reactions, serial dilutions of GAPDH standard were amplified with aliquots of the same cDNA pool. GAPDH quantitation was achieved by performing a linear regression of $\log$ (signal standard/signal cDNA) with $\log$ (known concentration of the standard). The point at which $\log$ (signal standard/signal cDNA) is zero is the equivalence point; the antilog gives the concentration of the specific cDNA. Values are corrected for differences in fragment size because equal numbers of the larger cDNA products will stain more strongly in proportion to the size difference.

For BDNF, a narrow range of standard dilutions was used. In this way, cDNA levels could be determined directly from the gel of PCR products without further analysis. The effective use of competitive PCR for the quantitation of BDNF mRNA was established by testing the following parameters: the equal competitiveness of each cDNA and its standard over a broad range of RNA concentrations; the reproducibility of quantitation over the same range; and its high level of sensitivity and specificity (Carding et al., 1992). This was accomplished by producing in vitro transcribed RNAs from a BDNF cDNA clone and its competitor. Equal amounts of the RNAs were tested by RT-PCR for ability to compete and for reliability. Southern hybridization of BDNF PCR products and other known neurotrophin cDNAs with a BDNF probe provided evidence of the specificity of the BDNF amplification. Finally, sensitivity was established by the ability to detect $10^{-3}$ amol of BDNF mRNA in mouse sciatic nerve preparations (Fig. 2).

Northern hybridization of CNTF $m R N A$. Because of its relative abundance in peripheral nerves, CNTF mRNA was assayed by Northern hybridization. Total RNA from three to five sciatic nerves was loaded per lane on formaldehyde-containing $1 \%$ agarose gels. RNA was transferred to Nytran membranes (Schleicher \& Schuell, Keene, NH) using a vacuum transfer apparatus (Pharmacia) and an ultraviolet crosslinker (Stratagene, La Jolla, CA). A 600 bp CNTF cDNA cloned into pGEM7Z was 

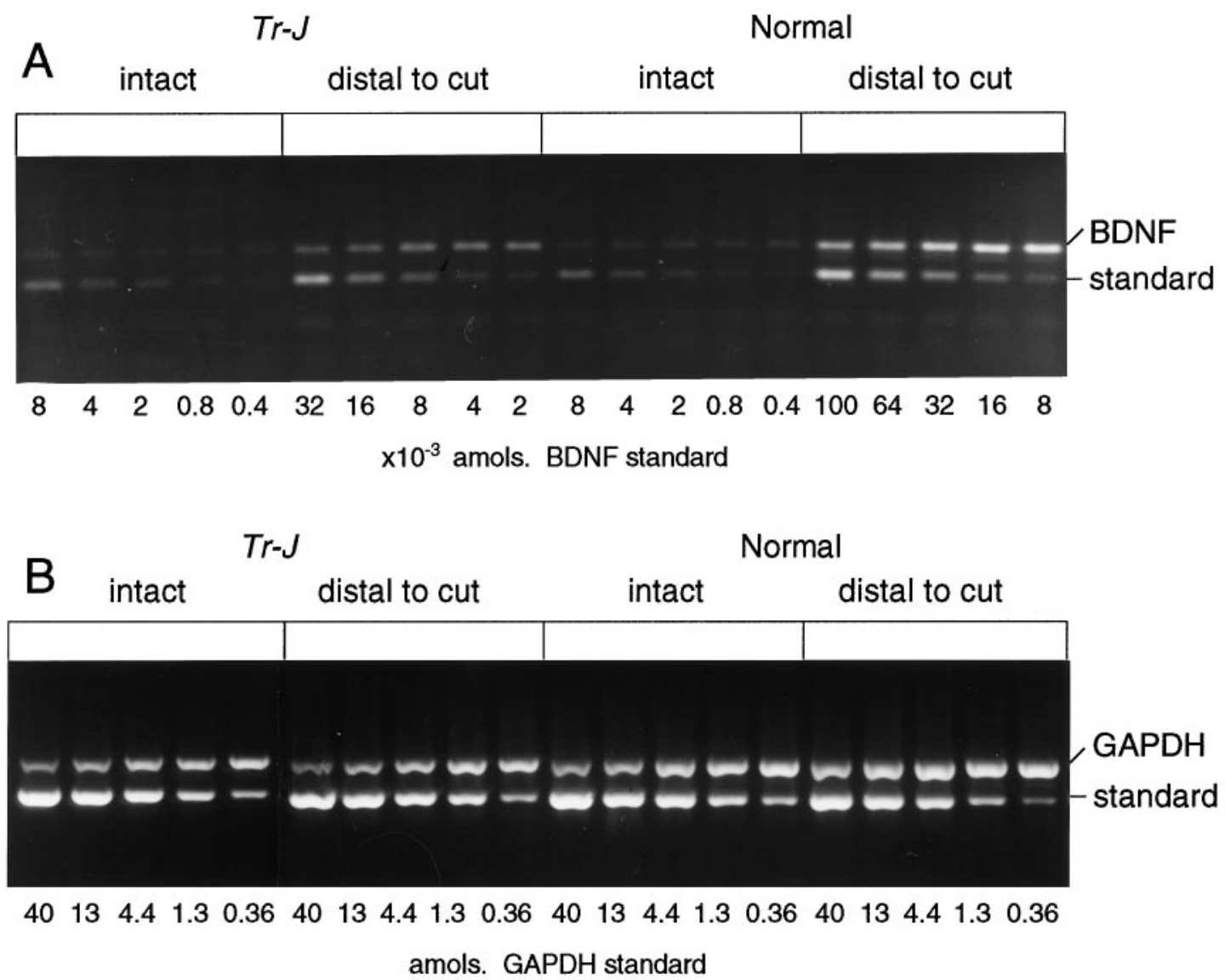

Figure 2. RT-PCR of BDNF and GAPDH mRNAs in Tr-J and normal sciatic nerves. RNA was purified from distal stumps of transected sciatic nerves 2 weeks after axotomy. Intact contralateral nerves were used as controls. After RT with random primers, the cDNA samples were amplified for BDNF $(A)$ and GAPDH $(B)$. Each sample was coamplified with a dilution series of five concentrations of the BDNF DNA standard. For example, in the intact Tr- $J$ nerves, the intensity of the BDNF cDNA band $(318 \mathrm{bp})$ is greater than the $8 \times 10^{-4}$ amol standard band $(197 \mathrm{bp})$ and less than the $4 \times 10^{-4}$ amol band, giving a measurement of $6-7 \times 10^{-4}$ amol for this sample. By the same procedure, the GAPDH mRNA of this sample was estimated to be 2.8 amol $(B)$, giving a ratio of $0.02 \% \mathrm{BDNF} / \mathrm{GAPDH}$.

a gift from Dr. R. J. Dunn. The purified cDNA fragment was labeled with $\left[{ }^{32} \mathrm{P}\right]$ deoxycytidine triphosphate $(3000 \mathrm{Ci} / \mathrm{mmol}$, Dupont NEN) using an oligolabeling kit (Pharmacia).

Hybridizations were performed overnight at $68^{\circ} \mathrm{C}$ as described previously (Jelsma et al., 1993) using $1-3 \times 10^{6} \mathrm{cpm} / \mathrm{ml}$ of probe in $0.5 \mathrm{M}$ $\mathrm{NaPO}_{4}, \mathrm{pH} 7,7 \%$ SDS, $1 \%$ bovine serum albumin, 1 mm EDTA, and 100 $\mu \mathrm{g} / \mathrm{ml}$ salmon sperm DNA. Filters were washed twice for $20 \mathrm{~min}$ each at $67^{\circ} \mathrm{C}$ in $4 \times \mathrm{SSC}, 0.1 \%$ SDS, and twice for $20 \mathrm{~min}$ in $2 \times \mathrm{SSC}, 0.1 \%$ SDS. The blots were then exposed to Kodak XAR film with intensifying screens at $-80^{\circ} \mathrm{C}$, stripped of probe by four washes in $0.1 \times \mathrm{SSC}$ at $85^{\circ} \mathrm{C}$ for 30 min each, and then re-probed for GAPDH mRNA. Total RNA was estimated by methylene blue staining. Blots were washed for $15 \mathrm{~min}$ at room temperature in 5\% acetic acid, then stained for $10 \mathrm{~min}$ at room temperature with $0.04 \%$ methylene blue in $0.5 \mathrm{~m}$ sodium acetate, $\mathrm{pH} 5.2$, and rinsed in water numerous times to remove the background staining. Autoradiograms were scanned using a SciScan 5000 densitometer (US Biochemical, Cleveland, $\mathrm{OH})$.

\section{RESULTS}

\section{Measurement of GAPDH mRNA levels}

As an internal reference, GAPDH levels were measured in the same cDNA pool as the BDNF. GAPDH mRNA was first assessed in each experimental situation to determine its expression relative to total RNA. As shown previously (Heumann et al., 1987), there were three- to fourfold increases in total RNA in the distal portions of the transected nerves; uninjured Tr-J nerves also contained several-fold more RNA than control nerves.
GAPDH RNA was measured in uninjured nerves and in the distal stumps of transected nerves from four normal and four Tr-J mice. As estimated by ethidium bromide staining intensity on agarose gels, equal amounts of RNA were used for RT followed by PCR for GAPDH. There was no significant difference in GAPDH/RNA ratios among RNA pools from these four groups (Table 1), indicating that GAPDH levels are a reliable reference for comparisons of trophic factor levels.

\section{BDNF mRNA in Tr-J and normal sciatic nerves}

For each experiment, RNA purified from the pooled sciatic nerves of three to five $T r$ - $J$ and three to five control mice was used to quantitate GAPDH and BDNF mRNAs by RT-PCR. Examples of competitive PCR for BDNF and GAPDH on the same RNA sample are shown

Table 1. GAPDH mRNA/total RNA in sciatic nerves

$($ mean $\pm \mathrm{SD} ; n=2-3$ )

\begin{tabular}{lll} 
& Normal & Tr-J \\
\hline Intact & $1.11 \pm 0.34$ & $0.80 \pm 0.22$ \\
Transected $^{a}$ & $0.72 \pm 0.20$ & $0.86 \pm 0.31$
\end{tabular}

${ }^{a}$ Distal stump, 2 weeks after sciatic nerve transection.

GAPDH cDNA was measured in 1/30 of cDNA pool reverse-transcribed from $1 \mu \mathrm{g}$ RNA. Values are expressed as amol/ $\mu \mathrm{g}$. 
Table 2. CNTF and GAPDH ratios in $T r-J$ and normal nerves

\begin{tabular}{llll} 
& \multicolumn{2}{l}{ Tr-J/normal } & \\
\cline { 2 - 4 } Preparation & CNTF & GAPDH & CNTF/GAPDH \\
\hline 1 & 0.38 & 2.08 & 0.18 \\
2 & 0.52 & 1.69 & 0.31 \\
3 & 1.72 & 5.88 & 0.29 \\
4 & 0.93 & 4.55 & 0.20 \\
& & & Mean \pm SD \\
\hline
\end{tabular}

For each preparation, sciatic nerve RNA was probed for CNTF and GAPDH mRNAs as described in Materials and Methods. Band intensities obtained by densitometric scanning of autoradiograms were used to compare CNTF and GAPDH signals in normal and $T r-J$ nerves. The consistently higher GAPDH signals in $T r-J$ nerves reflect the increased amounts of RNA obtained from these nerves (see Fig. 4B).

in Figure 2. When reverse transcriptase was omitted from the reaction, the cDNA signal was not observed (data not shown), indicating that there was no DNA contamination. The levels of BDNF mRNA in intact sciatic nerves were at the limit of detection in this assay; in both the $T r-J$ or normal mouse sciatic nerves, the BDNF/GAPDH ratios were $0.03 \pm 0.02 \%$.

\section{CNTF Northern analysis of $\operatorname{Tr}-\mathrm{J}$ and normal sciatic nerves}

CNTF Northern blot hybridizations of total RNA from normal or Tr-J sciatic nerves showed a single band of $\sim 1.2 \mathrm{~kb}$, as reported previously (Stöckli et al., 1989). CNTF mRNA levels were lower in the mutant than in control nerves, whereas GAPDH mRNA levels were consistently higher (Fig. 3). The CNTF/GAPDH mRNA ratios for the Tr-J sciatic nerves were $25 \%$ of those of normal nerves (Table 2).

\section{Effects of axonal interruption}

BDNF mRNA is markedly upregulated in the distal portion of transected rat sciatic nerves (Meyer et al., 1992; Funakoshi et al., 1993). To determine if the Tr-J SCs retain their ability to upregulate BDNF mRNA after injury, BDNF mRNA levels were compared after sciatic nerve transection in mutant and control mice (Fig. 2). After such lesions, BDNF mRNA levels were significantly greater in the control nerves than in the Tr-J nerves (Fig. 4). Fourteen days after transection, the levels of BDNF mRNA increased approximately 70 -fold in the distal segments of normal sciatic nerves, but only 30 -fold in $T r-J$ mouse nerves. Thus, the extent to which $T r-J$ nerves upregulate BDNF mRNA is less than that of normal nerves.

To examine BDNF regulation in a population of SCs that normally does not produce myelin, BDNF and GAPDH mRNAs were measured in the distal portions of rat CSTs 1 and 2 weeks after axonal interruption (Figs. 4, 5). The rat CST was used for this study because of the small size of this nerve in the mouse. In the RNA prepared from six intact CSTs, the BDNF mRNA level was below the detection limit of the experiment $(\leq 0.0004$ amol). After injury, however, total RNA increased and BDNF mRNA became detectable, but the BDNF/GAPDH ratio was only $0.09 \%$ for the crushed nerves and $0.05 \%$ for the transected nerves (Fig. 4). These ratios are 20- to 40-fold lower than the BDNF/GAPDH ratio for axotomized sciatic nerves from normal mice $(2.0 \pm 0.5 \%)$ or rats $(2.2 \pm 0.5 \%$, details of data not shown, $n=2$ ). Thus, in response to injury, the

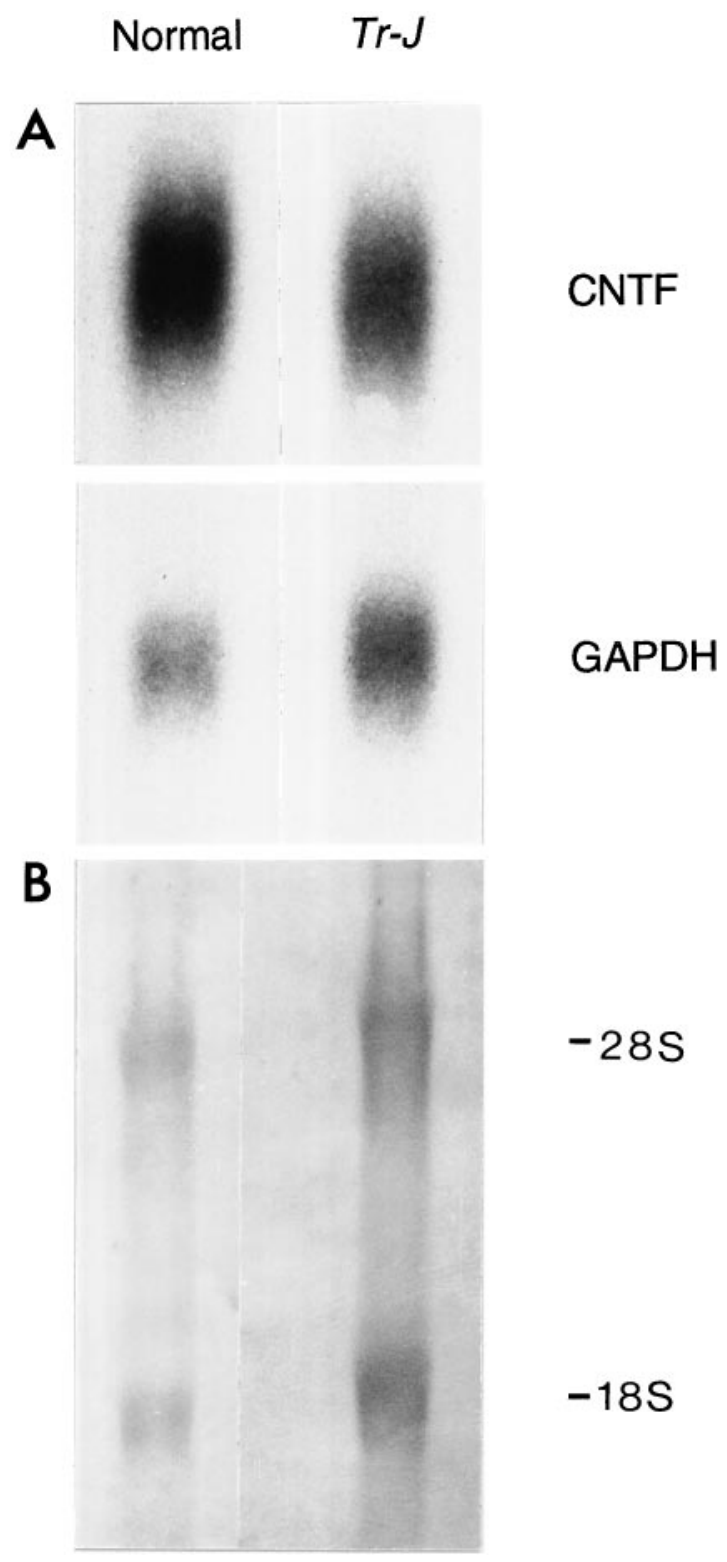

Figure 3. Northern blot of CNTF and GAPDH RNAs in normal and Tr- $J$ sciatic nerves. Total RNA from 3-5 sciatic nerves of control and $T r-J$ mice was processed for Northern blot hybridization as described in Materials and Methods $(A)$. The blot was first hybridized with a CNTF cDNA probe and subsequently rehybridized with a GAPDH cDNA probe. In the Tr-J nerves, the GAPDH mRNA was proportional to the main rRNA species (18S and 28S), visualized when the blot was stained with methylene blue $(B)$. $S$, Svedberg units.

predominantly unmyelinated CST does not upregulate BDNF mRNA as does the sciatic nerve, which contains many more myelinated fibers.

Previous investigators showed that 1 week after transection of normal rat sciatic nerves, CNTF mRNA is reduced by $98 \%$ (Friedman et al., 1992; Sendtner et al., 1992b). CNTF Northern blot hybridization of RNA extracted from the distal portions of four transected sciatic nerves of normal and $T r-J$ mice agreed with these results. After axotomy, CNTF mRNA expression decreased by more than 10 -fold in normal nerves and was reduced to a comparable extent in $\operatorname{Tr}$-J nerves (data not shown). 


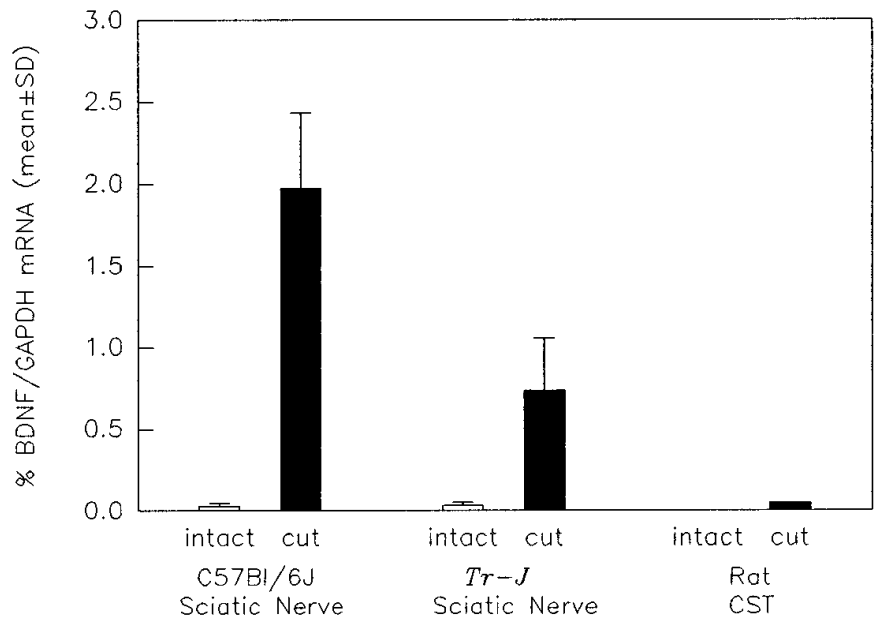

Figure 4. Effect of transection on BDNF/GAPDH ratios in sciatic nerves from control $(C 57 B l / 6 J)$ and $T r$ - $J$ mice and in rat CSTs. BDNF and GAPDH mRNAs were quantitated using competitive RT-PCR (as in Fig. 2) of RNA purified from the distal segments of transected and uninjured nerves. After transection (black bars), the mean \pm SD of BDNF/GAPDH ratios are increased for both the normal $(p=0.02)$ and Tr-J nerves $(p=$ 0.04; Mann-Whitney rank sum test). In addition, the increase in BDNF/ GAPDH ratio was significantly less for the $T r-J$ nerves than the controls ( $p=0.01$; Student's $t$ test). BDNF mRNA was not detectable in the RNA prepared from the intact rat CSTs; 2 weeks after transection, the BDNF/ GAPDH ratio was substantially less in the CST than in the sciatic nerve preparations.

\section{DISCUSSION}

These investigations, designed to determine the role of SC differentiation and myelin formation in the expression of BDNF or CNTF in peripheral nerves, have demonstrated the following. (1) Using an RT-PCR method that is sensitive to the range of $1 \mathrm{amol}$, the expression of BDNF mRNA in Tr- $J$ sciatic nerves remains at the same low level as in normal controls, despite the severe pathological changes in the $T r-J$ nerves. (2) An upregulation of BDNF mRNA could be triggered in Tr- $J$ sciatic nerves by interrupting axonal continuity, but the enhancement of BDNF expression in the hypomyelinated $T r$ - $J$ nerves was less than one-half that observed after the same injury in normally myelinated nerves. (3) BDNF mRNA was not detectable in the intact CST of adult rats, where $\sim 1 \%$ of axons are ensheathed by myelin (Bray and Aguayo, 1974). (4) After axonal interruption, BDNF mRNA expression in the rat CST barely changed from normal, reaching levels that were 20- to 40-fold less than in transected sciatic nerves. The slight increase in BDNF in the CST after injury likely reflects the small population of myelinated fibers in this nerve. (5) Compared with intact control nerves, CNTF mRNA levels were fourfold less in intact $T r-J$ sciatic nerves and decreased further after axonal interruption to approximate the levels found in axotomized control nerves.

\section{Expression of BDNF mRNA in peripheral nerves}

Our findings that BDNF mRNA levels in intact $T r-J$ nerves did not differ from normal controls indicate that demyelination and SC proliferation per se may not trigger or sustain an enhanced expression of BDNF. Such an upregulation might have been expected from previous observations of a marked increase in the mRNAs of most neurotrophins, including BDNF, in the distal stumps of transected sciatic nerves (Heumann et al., 1987; Meyer et al., 1992; Funakoshi et al., 1993) where myelin degenerates and SCs divide after axotomy. However, the temporal relationships of
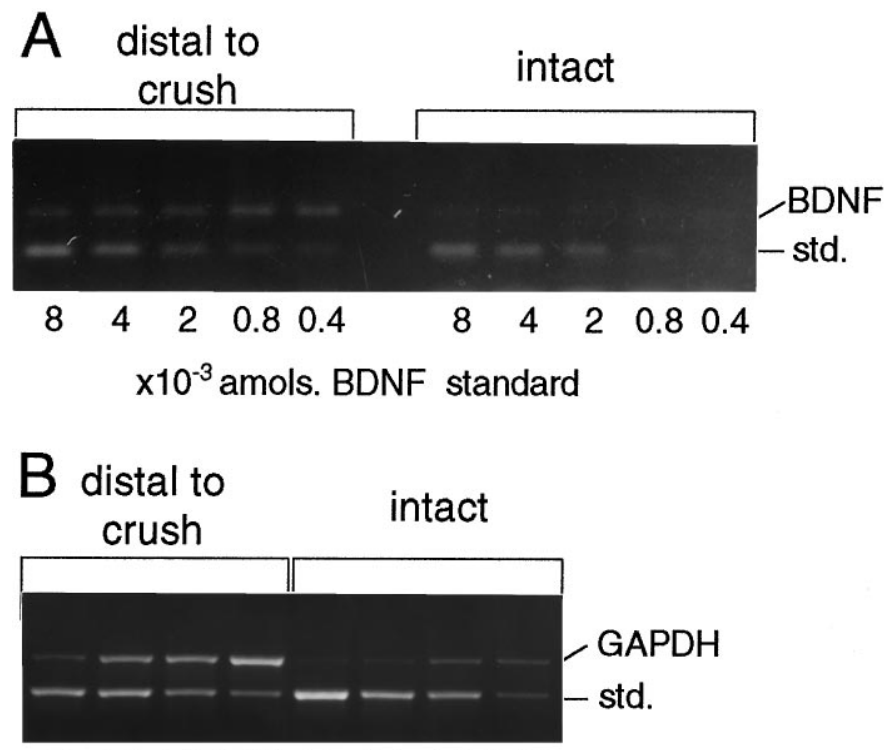

$13 \quad 4.41 .30 .3613 \quad 4.41 .30 .36$

\section{amols. GAPDH standard}

Figure 5. RT-PCR of BDNF and GAPDH mRNAs in CSTs after nerve crush. RNA was purified from four intact and four distal stumps of crushed rat CSTs 1 week after axotomy. The cDNA pool produced by random-primed RT was amplified in PCR for BDNF $(A)$ and GAPDH $(B)$. The GAPDH measurements for intact and crushed CSTs were 0.4 and $2.2 \mathrm{amol}$. The BDNF level of four intact CSTs was less than or equal to the detection limit of $0.0004 \mathrm{amol}$; crushed CSTs measured $0.0016 \mathrm{amol}$ BDNF. The average BDNF/GAPDH ratio of two experiments with crushed CSTs was $0.09 \pm 0.01 \%$. std., Standard.

myelin breakdown or SC proliferation do not coincide with maximum BDNF expression during Wallerian degeneration. The removal of myelin debris is virtually complete $6 \mathrm{~d}$ after sciatic nerve transection in mice (Reichert et al., 1994). Furthermore, SC proliferation peaks during the first week after axotomy when BDNF values are only beginning to rise. In transected nerves, high and sustained levels of BDNF occur later when SC labeling indices are low (Bradley and Asbury, 1970) and resemble those found in the intact Tr-J nerves (Perkins et al., 1981).

The role of axonal contacts in the regulation of neurotrophin expression by SCs is emphasized by our finding that BDNF mRNA expression is enhanced after $T r-J$ sciatic nerve transection. However, this response to axotomy was weaker than normal in $T r-J$ sciatic nerves and even less in the interrupted fibers of normal CSTs, which are predominantly unmyelinated (Fig. 4). The blunted increase in BDNF mRNA in transected $T r-J$ sciatic nerves may relate to the incomplete SC differentiation and scant myelin formation in this mutant. Because of the small size of the mouse CST, changes in BDNF expression after injury to unmyelinated fibers were documented only in rats. Nevertheless, we believe that our conclusion that there are differences in the expression of trophic factors by myelinating and nonmyelinating SCs is justified for two additional reasons. (1) CNTF expression is high in rat sciatic nerves but low in the CSTs of the same animal (Friedman et al., 1992). (2) After sciatic nerve injury, BDNF mRNA is upregulated in both rats (Meyer et al., 1992; Funakoshi et al., 1993) and mice (Fig. 2). Thus, our present studies in the rat CST establish the existence of unequal neurotrophin expression in myelinated and unmyelinated fibers in rats. These observations, together with those in Tr-J sciatic nerves, suggest that BDNF 
expression after axonal injury is restricted to SCs that have differentiated toward a myelinating phenotype. Although it has not been possible to define the precise state of differentiation that is required for such responses, it is likely that the early expression of myelin genes and myelin products seen at the premyelinating stage is needed.

\section{Expression of CNTF mRNA in peripheral nerves}

Several observations have led to the suggestion that CNTF expression is governed by axon-SC interactions (Friedman et al., 1992): the correlation of CNTF expression during development with myelin formation and the cessation of SC proliferation (Sendtner et al., 1990); the localization of CNTF to SCs of myelinated rather than unmyelinated fibers (Friedman et al., 1992); and, the fall in CNTF levels during Wallerian degeneration (Sendtner et al., 1992b). Our demonstration of decreased CNTF mRNAs in $T r-J$ nerves with preserved axons extends these ideas and suggests that axonal influences may not be primarily involved in the regulation of this cytokine. Apparently, SCs may need to stop dividing and acquire a stable myelinated phenotype for CNTF expression to reach its peak (Sendtner et al., 1990; Friedman et al., 1992). However, myelin formation and CNTF levels appear to be regulated by different intracellular pathways; an elevation of cAMP induces myelin synthesis but does not affect CNTF expression (Carroll et al., 1993). Thus, the downregulation of this molecule appears to be a sensitive but less specific indicator of a range of perturbations of peripheral nerve when SC changes are induced by axotomy or primary disorders of myelination.

\section{Possible effects of low trophic factor expression by non-neuronal cells}

Reductions in axon caliber are a common finding in segmentally demyelinated nerve fibers of the PNS and CNS (Raine et al., 1969). In the peripheral nerves of $T r-J$ mice, axon caliber is decreased (Low, 1976) and neurofilament phosphorylation is impaired (de Waegh et al., 1992). Transplantation of non-neuronal cells from normal mice into $T r$ - $J$ nerves leads to the formation of normal myelin sheaths, the curtailment of SC division, the return of axonal caliber to normal (Aguayo et al., 1976), and an increase in neurofilament phosphorylation (de Waegh et al., 1992). Although there is no proof that the decreased CNTF levels in Tr-J nerves contribute to the axonal changes seen in these animals, it is of interest that motor neurons in CNTF knock-out mice were normal at 4 weeks of age, but became atrophic by 8 weeks (Masu et al., 1993). The possibility that low levels of CNTF in Tr-J nerves might be related to the caliber and function of axons in this neuropathy is also supported by observations on the effect of exogenous CNTF on motoneuron function in three mouse mutants that have motoneuron disorders: wobbler (Mitsumoto et al., 1994), mnd (Helgren et al., 1992), and pmn (Sendtner et al., 1992a).

The long-standing decrease in CNTF expression found in Tr-J nerves also may play a role in the development of muscle fiber atrophy, a change that implies impaired innervation (Low, 1976). The observation that CNTF administration can reduce muscle fiber atrophy after denervation is consistent with this idea (Helgren et al., 1994).

\section{Potential relevance to human demyelinating disorders}

Both the Tr-J neuropathy in mice and Charcot-Marie-Tooth neuropathy type Ia (CMT-Ia) in humans exhibit marked deficits of myelination and mutations in the pmp-22 gene (Valentijn et al., 1992). These similarities raise the possibility that the pattern of trophic factor expression we describe in $T r-J$ may also be present in the nerves of patients with CMT and in other disorders of myelination. Axonopathies, in which neuronal alterations lead to axonal degeneration, constitute another well recognized group of animal and human neuropathies in which patterns of growth factor expression may be anticipated to exhibit features that resemble the axotomy-induced changes observed experimentally in this and other studies. Because both axonal changes and segmental demyelination coexist in most neuropathies, they are likely to show a wide spectrum of growth factor responses.

\section{Peripheral nerves as sources of neurotrophins}

The effectiveness of peripheral nerve grafts in promoting the lengthy regrowth of a population of CNS axons has been attributed in part to the capacity of SCs to release or enhance the expression of trophic molecules after peripheral nerve injury (Aguayo et al., 1991). However, the expression of BDNF (present results) or CNTF (Friedman et al., 1992) is low in unmyelinated nerves, even after injury. We have also found that BDNF mRNA expression in the rat optic nerve is not upregulated after transection (our unpublished results). Thus, the failure of BDNF mRNA to increase after injury in both peripheral unmyelinated fibers and CNS structures such as the optic nerve suggests certain similarities between the responses of nonmyelinating SCs and astrocytes. Because most axons in sensory or autonomic nerves, and many in mixed nerves such as the sciatic, are normally ensheathed by nonmyelinating SCs, the role of these cells in supporting the survival and growth of injured neurons may be different from that assumed for the SCs of myelinated nerve fibers.

In summary, our observations in $T r-J$ mice indicate that the SC disorder that selectively impairs myelination in the nerves of these mutants results in a moderate decrease in CNTF mRNA levels and no enhancement of BDNF mRNA expression. This pattern contrasts with the upregulation of neurotrophin expression and sharp fall in CNTF levels that follow axonal damage. The complexities of growth factor regulation in the PNS are illustrated by the known heterogeneity of neurotrophin receptors found on the neurons that give rise to peripheral axons (McMahon et al., 1994). As shown here, such complexities are further underscored by the differences in CNTF and BDNF expression in SCs at various stages of differentiation toward myelination. Moreover, our findings and those of Friedman et al. (1992) suggest that the SCs of unmyelinated nerve fibers may either not be an important source of trophic support or have trophic roles that are distinct from those of myelinated nerve fibers.

\section{REFERENCES}

Acheson A, Barker PA, Alderson RF, Miller FD, Murphy RA (1991) Detection of brain-derived neurotrophic factor-like activity in fibroblasts and Schwann cells: inhibition by antibodies to NGF. Neuron 7:265-275.

Aguayo AJ, Epps J, Charron L, Bray GM (1976) Multipotentiality of Schwann cells in cross-anastomosed and grafted myelinated and unmyelinated nerves. Quantitative microscopy and radioautography. Brain Res 104:1-20.

Aguayo AJ, Rasminsky M, Bray GM, Carbonetto S, McKerracher L, Villegas-Pérez MP, Vidal-Sanz M, Carter DA (1991) Degenerative and regenerative responses of injured neurons in the central nervous system of adult mammals. Philos Trans R Soc Lond Biol 331:337-343.

Ayers MM, Anderson RM (1973) Onion bulb neuropathy in the Trembler mouse: a model of hypertrophic interstitial neuropathy (DejerineSottas) in man. Acta Neuropathol 25:54-70.

Bradley WG, Asbury AK (1970) Duration of synthesis phase in neurilemma cells in mouse sciatic nerve during degeneration. Exp Neurol 26:275-282.

Bray GM, Aguayo AJ (1974) Regeneration of peripheral unmyelinated nerves. Fate of the axonal sprouts which develop after injury. J Anat 117:517-529. 
Bunge RP (1993) Expanding roles for the Schwann cell: ensheathment, myelination, trophism and regeneration. Curr Opin Neurobiol 3:805-809.

Carding SR, Dandan L, Bottomly K (1992) A polymerase chain reaction assay for the detection and quantitation of cytokine gene expression in small numbers of cells. J Immunol Methods 151:277-287.

Carroll P, Sendtner M, Meyer M, Thoenen H (1993) Rat ciliary neurotrophic factor (CNTF): gene structure and regulation of mRNA in glial cell cultures. Glia 9:176-187.

Chomczynski P, Sacchi N (1987) Single-step method of RNA isolation by acid guanidinium thiocyanate-phenol-chloroform extraction. Anal Biochem 162:156-159.

Coen DM (1991) The polymerase chain reaction. In: Current protocols in molecular biology (Janssen K, ed), pp 15.0.1-15.7.6. New York: Wiley.

de Waegh SM, Lee VM-Y, Brady ST (1992) Local modulation of neurofilament phosphorylation, axonal caliber, and slow axonal transport by myelinating Schwann cells. Cell 68:451-463.

Friedman B, Scherer SS, Rudge JS, Helgren M, Morrisey D, McClain J, Wang DY, Wiegand SJ, Furth ME, Lindsay RM (1992) Regulation of ciliary neurotrophic factor expression in myelin-related Schwann cells in vivo. Neuron 9:295-305.

Funakoshi H, Frisén J, Barbany G, Timmusk T, Zachrisson O, Verge VMK, Persson H (1993) Differential expression of mRNAs for neurotrophins and their receptors after axotomy of the sciatic nerve. J Cell Biol 123:455-465.

Gilliland GS, Perrin S, Blanchard K, Bunn HF (1990) Analysis of cytokine mRNA and DNA: detection and quantitation by competitive polymerase chain reaction. Proc Natl Acad Sci USA 87:2725-2729.

Helgren ME, Friedman B, Kennedy M, Mullholland K, Messer A, Wong VBB, Lindsay RM (1992) Ciliary neurotrophic factor (CNTF) delays motor impairments in the mnd mouse, a genetic model of motor neuron disease. Soc Neurosci Abstr 267:618.

Helgren ME, Squinto SP, Davis HL, Parry DJ, Boulton TG, Heck CS, Zhu Y, Yancopoulos GD, Lindsay RM, DiStefano PS (1994) Trophic effect of ciliary neurotrophic factor on denervated skeletal muscle. Cell 76:493-504.

Heumann R, Korshing S, Bandtlow C, Thoenen H (1987) Changes in nerve growth factor synthesis in non-neuronal cells in response to sciatic nerve transection. J Cell Biol 104:1623-1631.

Jelsma TN, Friedman HH, Berkelaar MJ, Bray GM, Aguayo AJ (1993) Different forms of the neurotrophin receptor trkB mRNA predominate in rat retina and optic nerve. J Neurobiol 24:23-36.

Kawasaki ES, Wang AM (1989) Detection of gene expression. In: PCR technology: principles and applications for DNA amplification (Erlich HA, ed), pp 89-97. New York: Stockton.

Low PA (1976) Hereditary hypertrophic neuropathy in the Trembler mouse. Part 1. Histopathological studies: light microscopy. J Neurol Sci 30:327-341.

Marchionni MA, Goodearl ADJ, Chen MS, Bermingham-McDonogh O, Kirk C, Hendricks M, Danehy F, Misumi D, Sudhalter J, Kobayashi K, Wroblewski D, Lynch C, Baldassare M, Hiles I, Davis JB, Hsuan JJ, Totty NF, Otsu M, McBurney RN, Waterfield MD, Stroobant P, Gwynne D (1993) Glial growth factors are alternatively spliced erbB2 ligands expressed in the nervous system. Nature 362:312-318.

Masu Y, Wolf E, Holtmann B, Sendtner M, Brem G, Thoenen H (1993) Disruption of the CNTF gene results in motor neuron degeneration. Nature 365:27-32.
McMahon SB, Armanini MP, Ling LH, Phillips HS (1994) Expression and coexpression of Trk receptors in subpopulations of adult primary sensory neurons projecting to identified targets. Neuron 12:1161-1171.

Meyer M, Matsuoka I, Wetmore C, Olson L, Thoenen H (1992) Enhanced synthesis of brain-derived neurotrophic factor in the lesioned peripheral nerve: different mechanisms are responsible for the regulation of BDNF and NGF mRNA. J Cell Biol 119:45-54.

Mirsky R, Jessen KR (1996) Schwann cell development, differentiation and myelination. Curr Opin Neurobiol 6:89-96.

Mitsumoto H, Ikeda K, Klinkosz B, Cedarbaum JM, Wong V, Lindsay RM (1994) Arrest of motor neuron disease in wobbler mice cotreated with CNTF and BDNF. Science 265:1107-1110.

Perkins S, Aguayo AJ, Bray GM (1981) Schwann cell multiplication in Trembler mice. Neuropathol Appl Neurobiol 7:115-126.

Raine CS, Wisniewski H, Prineas J (1969) An ultrastructural study of experimental demyelination and remyelination. II. Chronic experimental allergic encephalomyelitis in the peripheral nervous system. Lab Invest 21:316-327.

Reichert F, Saada A, Rotshenker S (1994) Peripheral nerve injury induces Schwann cells to express two macrophage phenotypes: phagocytosis and the galactose-specific lectin MAC-2. J Neurosci 14:3231-3245.

Reynolds ML, Woolf CJ (1993) Reciprocal Schwann cell-axon interactions. Curr Opin Neurobiol 3:683-693.

Salzer JL, Bunge RP, Glazer L (1980) Studies of Schwann cell proliferation. III. Evidence for the surface localization of the neurite mitogen. J Cell Biol 84:767-778.

Schecterson LC, Bothwell M (1992) Novel roles for neurotrophins are suggested by BDNF and NT-3 mRNA expression in developing neurons. Neuron 9:449-463.

Sendtner M, Kreutzberg GW, Thoenen H (1990) Ciliary neurotrophic factor prevents the degeneration of motor neurons after axotomy. Nature 345:440-441.

Sendtner M, Schmalbruch H, Stöckli KA, Carroll P, Kreutzberg GW, Thoenen H (1992a) Ciliary neurotrophic factor prevents degeneration of motor neurons in mouse mutant progressive motor neuronopathy. Nature 358:502-504.

Sendtner M, Stöckli KA, Thoenen H (1992b) Synthesis and localization of ciliary neurotrophic factor in the sciatic nerve of the adult rat after lesion and during regeneration. J Cell Biol 118:139-148.

Sendtner M, Carroll P, Holtmann B, Hughes RA, Thoenen H (1994) Ciliary neurotrophic factor. J Neurobiol 25:1436-1453.

Stöckli KA, Lottspeich F, Sendtner M, Masiakowski P, Carroll P, Götz R, Lindholm D, Thoenen H (1989) Molecular cloning, expression and regional distribution of rat ciliary neurotrophic factor. Nature 342:920-923.

Suter U, Moskow JJ, Welcher AA, Snipes GJ, Kosaras B, Sidman RL, Buchberg AM, Shooter EM (1992) A leucine-to-proline mutation in the putative first transmembrane domain of the $22 \mathrm{kDa}$ peripheral myelin protein in the trembler-J mouse. Proc Natl Acad Sci USA 89:4382-4386.

Valentijn LJ, Baas F, Wolterman RA, Hoogendijk JE, van den Bosch NH, Zorn I, Gabreels-Festen AW, De Visser M, Bolhuis PA (1992) Identical point mutations of PMP-22 in Trembler-J mouse and CharcotMarie-Tooth disease type 1A. Nature Genetics 2:288-291.

Williams LR, Manthorpe M, Barbin G, Nieto-Sampedro M, Cotman CW, Varon S (1984) High ciliary neuronotrophic specific activity in rat peripheral nerve. Int J Dev Neurosci 2:177-180. 